\title{
STUDENT'S ENTREPRENEURSHIP INTEREST IN TERMS OF CONTEXTUAL AND PERSONAL FACTOR
}

\author{
Tegowati ${ }^{* 1}$, Dian Palupi*), and Widhi Ariestianti Rochdianingrum*) \\ *) Sekolah Tinggi Ilmu Ekonomi Indonesia (STIESIA) Surabaya \\ Jl. Menur Pumpungan No.30 Sukolilo, Surabaya, East Jawa 60118
}

\begin{abstract}
This study aims to review the interests of student entrepreneurship from contextual factors and personal factors. The population in this study was students in East Java with a total sample of 125 . The sampling technique used was accidental sampling and data analysis using SEM. The results of this study are: 1) there is an influence of the contextual factors on the interest in entrepreneurship. This is based on standardized output parameter coefficient of 0.524 with $p=* * *$ (significant at $p=0.001$ ). 2) There is an influence of personality factors on the interest in entrepreneurship. This is indicated by the standardized output parameter coefficient of 0.472 which is significant at $p=0.001(p$ $=* * *$ ). The conclusion of this study is contextual factors and personality factors influence the interest in student entrepreneurship.
\end{abstract}

Keywords: interest in entrepreneurship, contextual factors, personality factors, student's entrepreneurship, improve student competency

\begin{abstract}
Abstrak: Penelitian ini bertujuan meninjau minat berwirausaha mahasiswa dari faktor kontekstual dan faktor kepribadian. Populasi dalam penelitian ini adalah mahasiswa di Jawa Timur dengan jumlah sampel sebanyak 125. Teknik sampling yang digunakan adalah Accidental Sampling dan analisis data menggunakan SEM. Hasil penelitian ini adalah 1) Terdapat pengaruh faktor kontekstual terhadap minat berwirausaha. Hal ini berdasarkan output standardized koefisien parameter sebesar 0,524 dengan $p=* * *$ (signifikan pada $p=0,001)$. 2)Terdapat pengaruh faktor kepribadian terhadap minat berwirausaha. Hal ini ditunjukkan oleh output standardized koefisien parameter sebesar 0,472 yang signifikan pada $p=0,001$ (tanda $p=* * *$ ). Kesimpulan penelitian ini adalah faktor kontekstual dan faktor kepribadian berpengaruh terhadap minat berwirausaha mahasiswa.
\end{abstract}

Kata kunci: minat berwirausaha, faktor konteksual, faktor kepribadian, kewirausahaan mahasiswa, meningkatkan kompetensi mahasiswa

\footnotetext{
${ }^{1}$ Corresponding author:

Email: tegowati@stiesia.ac.id
} 


\section{INTRODUCTION}

In the University of Environment, the phenomenon of entrepreneurship is one of the efforts to improve student competence and increase the success rate of higher education. Students are expected to be able to become entrepreneurs' initiators and creators of successful jobs in various business opportunities. Because, with entrepreneurship, there are so many benefits that can be taken, among others, possessing, opportunities, benefits, as optimal as possible, and free, making what is needed, making it easier, will be more enjoyable.

This entrepreneurial issue is increasingly effective, especially in the university environment through the application of entrepreneurship education and training on campus as well as practice or application in the field. This is done so that college graduates do not only think of looking for work according to their undergraduate degree with an appropriate salary, but they can also find and create business opportunities for themselves and others because they have had sufficient debriefing while in college.

Ciputra (2009) argues that entrepreneurship is the right solution to solve the problem of unemployment and poverty in Indonesia, because by only armed with a diploma without entrepreneurial skills, prepare your self to queue for work because currently the supply of labor for college graduates is not comparable with job opportunities available. Entrepreneurial orientation has a positive and significant influence on intellectual resources (Paulus).

However, the fact in the field at this time states that there are still few entrepreneurs from among students. Based on data from the central statistical agency, it was noted that the number of students in East Java in $2014 / 2015$ amounted to 747,952 and the percentage of entrepreneurs was associated with the national population of entrepreneurs in Indonesia in 2015 still $1.6 \%$ and increased to $3.7 \%$ in 2017 . However, the number is still far behind other countries such as Malaysia 5\%, Singapore 7\%, and Thailand 4.5\%. For this reason, guidance and motivation are still needed to be able to change the perspective of college graduates so that they do not tend to become job seekers and are interested in entrepreneurship, including student backgrounds from contextual factors and personality factors.
Mopangga (2014) states that entrepreneurial interests are strongly influenced by the support of parents and families who are majority private employers and employees, public perceptions and the climate of entrepreneurial learning and academic support. Contextual factors proved to have a positive influence on the interest in entrepreneurship (Kadarsih et al. 2013). Personality and environment have an influence on entrepreneurial intentions (Pujiastuti, 2013). Entrepreneurial behavior is influenced by individual factors (Amir et al. 2018). Contextual factors have a significant and positive effect on students' entrepreneurial intentions (Walipah and Naim, 2016). Positive proactive personality and significant influence on entrepreneurial intentions (Aryaningtyas, 2018).

If the business is established because of the encouragement from within the entrepreneur, then there is a relatively higher desire to develop the business (Inggarwati and Kaudin, 2010). Personality and family environment have a significant effect on the interest in entrepreneurship (Yusuf et al. 2017). There is a significant positive effect of personality on the interest in entrepreneurship (Baskara and Has, 2018). Internationalization of new international businesses is determined by previous entrepreneurial characteristics entrepreneurial experience, recognition of opportunities and exploitation, risk tolerance, specific organization, networks and contextual involvement factors (Matiusinaite and Sekliuckiene, 2015). There is a positive and significant influence between socio demographic factors, attitudes, and contextual on the intention of entrepreneurship (Rochayati et al. 2013). Personality and knowledge have a significant effect on the interest in entrepreneurship (Nugrahaningsih and Muslim, 2016).

Personality factors have a significant effect on the interests of entrepreneurs (Sholikha and Harti, 2014). Tong et al. (2011) explain that students come from families entrepreneurs are important factors to start entrepreneurship in the future come. Contextual factors namely, academic support and social support are contextual factors that have a significant and positive influence on intention entrepreneurship (Suharti and Sirine, 2011). Furthermore, Suharti and Sirine (2011) also states that other contextual factors, namely the level of participation students in entrepreneurship training/ education, and business environment conditions (environmental support) is not proven to affect 
entrepreneurial intentions college student. Personality determines entrepreneurial intention, Indarti dan Rostiani (2008).

Then the Talas etal.(2013) study shows that the selection of faculty, high school background and family income is a significant factor that influences entrepreneurial intentions. Based on a growing phenomenon, researchers are interested in analyzing the influence of contextual factors and personality factors on the interest in entrepreneurship. The scope of this study includes students in East Java, namely students of the Surabaya School of Economics (STIESIA), UNISLA Lamongan, University of Muhammadiyah Malang, and University of Muhammadiyah Gresik. The scope of the study of interest in student entrepreneurship was viewed from two factors, namely contextual factors and personality factors.

\section{METHODS}

This research is a type of quantitative research because the data of this study are presented in the form of numbers and the data are analyzed using statistics. Sources of data obtained from primary data, namely through the distribution of questionnaires to respondents. The population in this study was all students in East Java who had participated in entrepreneurship courses.

The number of samples of this study amounted to 125 with the accidental sampling approach. Determination of the number of samples in this study refers to the sample size guideline proposed by Ferdinand (2014), the sample is calculated by multiplying the number of indicators with multiplication ranges, ranging from the smallest to the largest multiplication range until the right sample size is found. The multiplication is as follows: 5 X $25=125$.

Ghozali (2011) suggests that: With the estimation model using Maximum Likelihood (ML) a minimum sample of 100 is required. Thus the number of samples 125 determined in this study has met the minimum sample size for the maximum Likelihood Estimation technique). The data analysis technique used is SEM regression with AMOS 22.0 software. Analysis techniques (SPSS regression and AMOS Regression) have the same calculation results. Each question is measured by 1-5 scales. The variables in this study were measured using indicators. As for the operational indicators and definitions of the full variables shown in Table 1.

Table 1. Operational definitions of variables

\begin{tabular}{|c|c|c|}
\hline Variables & Operational definition variable & Dimensions / Indicators \\
\hline $\begin{array}{l}\text { Interest in } \\
\text { Entrepreneurship }\end{array}$ & $\begin{array}{l}\text { Student interest in business } \\
\text { activities that require courage in } \\
\text { taking risks gaining profits. }\end{array}$ & $\begin{array}{l}\text { Based on interest categories: 1) Not interested in entrepreneurship. } \\
\text { 2) Already interested. 3) Already running a business. 4) Never } \\
\text { had a business before, but failed; Based on time perspective: 1) } \\
\text { Interest in entrepreneurship in the near term / after graduation. } \\
\text { 2) Interest in entrepreneurship in the next two years. 3) Interest } \\
\text { in entrepreneurship in the long term / in the future. 4) Not yet } \\
\text { determined the time to start (Venesaar et al. in Uswaturrasul and } \\
\text { Sisilia, 2015). }\end{array}$ \\
\hline $\begin{array}{l}\text { Personality } \\
\text { factors }\end{array}$ & $\begin{array}{l}\text { A unique and relatively } \\
\text { permanent character that gives } \\
\text { consistency and individuality to } \\
\text { one's behavior. }\end{array}$ & $\begin{array}{l}\text { Confidence; Task oriented and results; Dare to take risks; } \\
\text { Leadership; Originality; Oriented to the future (Marbun in Alma, } \\
\text { 2013). }\end{array}$ \\
\hline $\begin{array}{l}\text { Contextual } \\
\text { factors }\end{array}$ & $\begin{array}{l}\text { Statement that } \\
\text { related to the true meaning of } \\
\text { entrepreneurship }\end{array}$ & $\begin{array}{l}\text { Dimensions of Academic Support (Academic Support): The } \\
\text { existence of people on campus who are successful because } \\
\text { of entrepreneurship; Encouragement to issue student ideas; } \\
\text { The existence of people on campus who have ideas for } \\
\text { entrepreneurship; Infrastructure support for the practice of } \\
\text { establishing new businesses on the premises. Dimensions of Social } \\
\text { Support: Family support; Support of closest friends; Support of } \\
\text { people who are considered important. Environmental conditions } \\
\text { (Environmental Support): Financial support; Administrative } \\
\text { procedure; Information about how to start a business; Economic } \\
\text { conditions / climate that are profitable for entrepreneurship (Autio } \\
\text { et al. } 2001 \text { in Gurbuz and Aykol, 2008). }\end{array}$ \\
\hline
\end{tabular}


Based on research background, previous research and developing phenomena, the hypothesis of this study are: H1 (There is an influence of contextual factors on the interest in entrepreneurship); H2 (There is an influence of personality factors on the interest in entrepreneurship). The two hypotheses presented in this study in full are shown in Figure 1.

\section{RESULTS}

\section{Exogenous Construct Confirmatory Test}

The confirmatory test results of exogenous constructs were carried out on contextual factors and personality factors. The test value of these two exogenous constructs has a convergent validity value above 0.50 so that the observed (indicator) of the exogenous construct is good. The following Figure 2 is the result of calculations on exogenous variables carried out on contextual factors and personality factors.

\section{Confirmatory Test of Endogenous Constructs}

The confirmatory test results of the endogenous interest in entrepreneurship show that the results of the standardized loading estimate test, indicators forming endogenous constructs of Entrepreneurship Interest have shown one-dimensional or valid because all indicators are $\geq 0.5$. Each value is $0.684 ; 0.627$; 0,$664 ; 0.623 ; 0,830 ; 0.702 ; 0.781 ; 0.0,77$. Thus the construct can be processed with a full model. The confirmatory test results of the endogenous interest in entrepreneurship in full are shown in Figure 3.

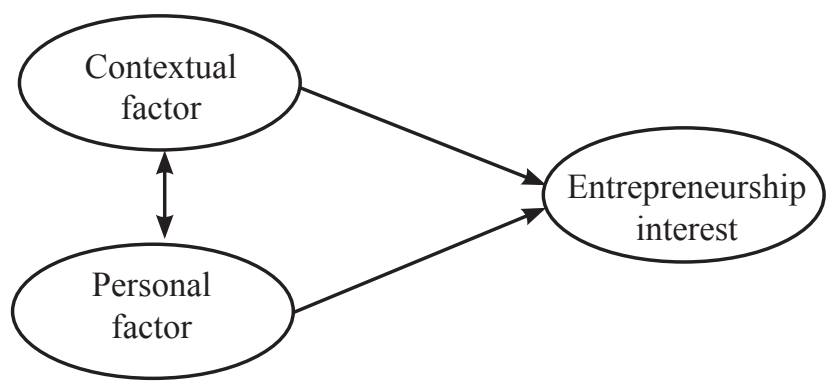

Figure 1. Conceptual framework

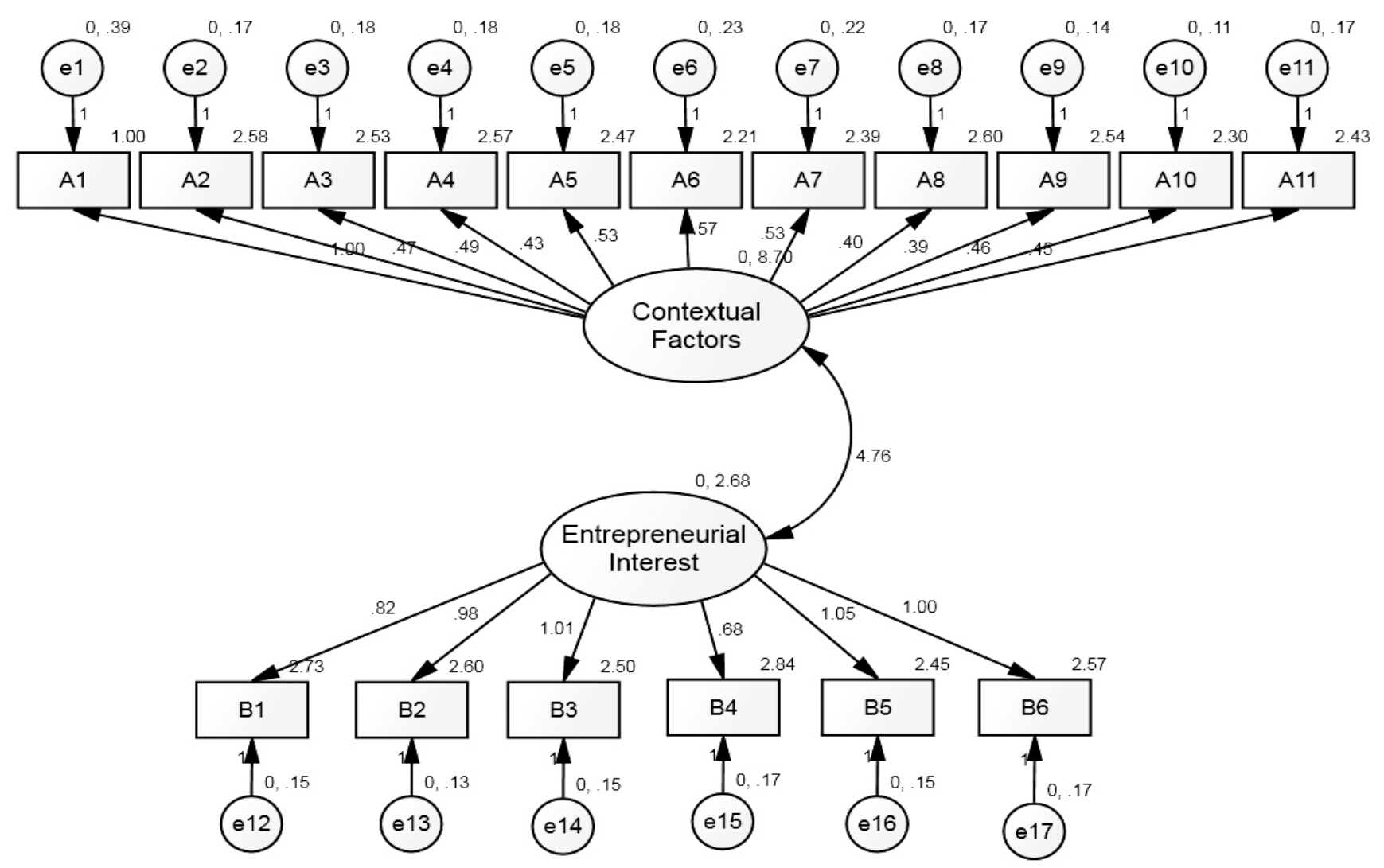

Figure 2. Confirmatory factor analysis between exogenous constructs 


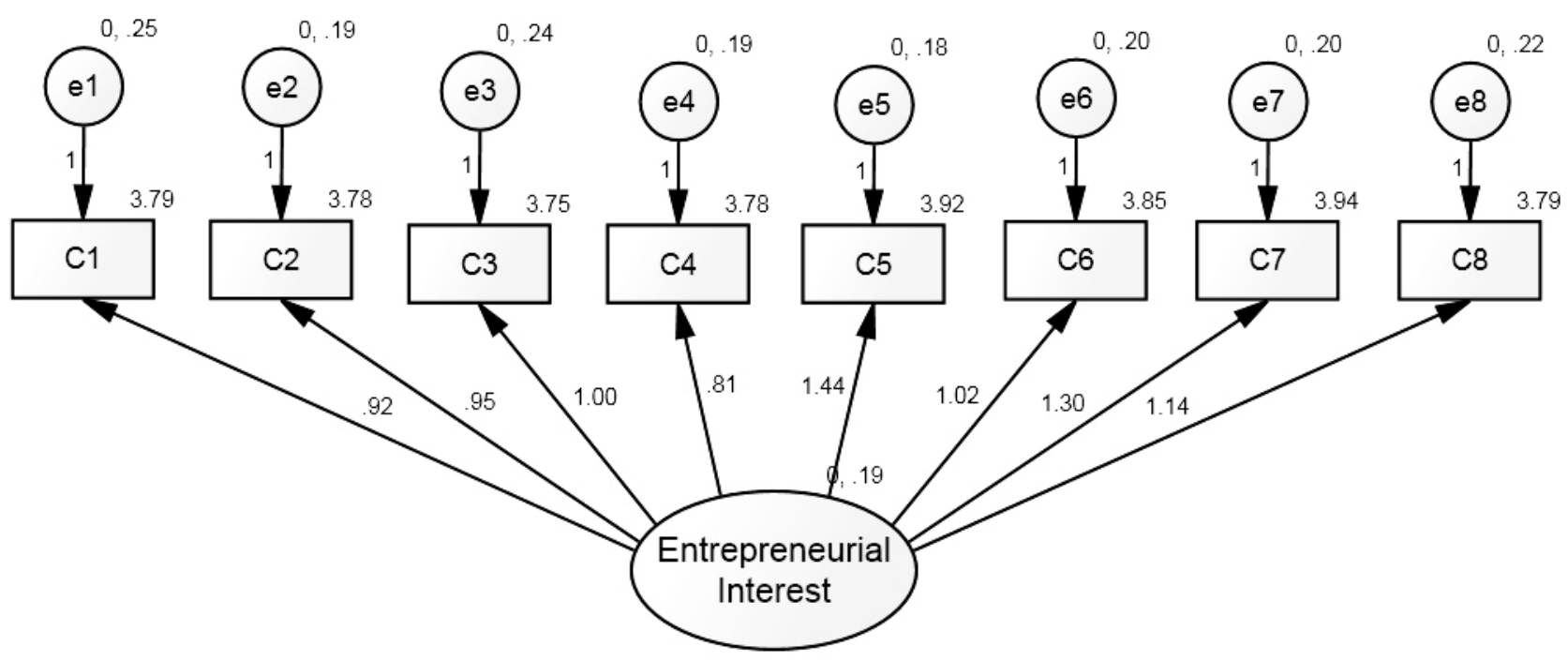

Figure 3. Confirmatory factor analysis of endogenous constructs

\section{Full Model SEM Analysis}

Analysis of the full structural model using SEM was carried out with insert indicators that have been confirmed confirmatory. The output results show goodness-fit value is quite good, Chi-square value = 989,820. The values of CMIN / DF, TLI, and CFI are all quite good. Thus the model is quite in accordance with the empirical data. The full SEM Model Analysis is shown in the Figure 4.

\section{Test Validity and Reliability}

Convergent Validity

In convergent validity calculations, the conditions that must be met are loading factors must be significant (loading estimate must be $\geq 0.50$ and ideally it should be 0.70 ). Based on the output of standardized loading estimate presented in Table 2, it shows that all statistically significant loading factors and loading values are above 0.50 .

\section{Variance Extracted}

The value of variance extracted $(\mathrm{AVE}) \geq 0.50$ shows a good convergent value. The calculation of AVE above shows that all constructs have good values, it is because $\geq 0.50$. AVE values are calculated for each latent construct as follows:
Calculation

- Interest in Entrepreneurship $\quad=0,912$

- Personality Factor $\quad=0.935$

- Contextual factors $\quad=0,854$

Construct Reliability $\Sigma$ Squared Standardized Loading:

- Interest in Entrepreneurship $\quad=7,300$

- Personality Factor $\quad=5,607$

- Contextual factors $\quad=9,225$

Variance Extracted

Construct Reliability 0.70 or more shows good reliability. While reliability of $0.60-0.70$ can still be accepted on the condition that the indicator validity is in good model. The value of reliability calculation shows that all constructs have a value above the cut-off value of 0.70 . Thus it can be concluded that the indicators in this study have good reliability. The calculation of construct Reliability is as follows:

Sum standardized loading:

- Interest in Entrepreneurship $=11,519$

- Personality Factor

$=5,800$

- Contextual factors

$=9,491$

$\Sigma$ Measurement Error:

- Interest in Entrepreneurship $=0,699$

- Personality Factor

$=0,392$

- Contextual factors

$=1,574$ 


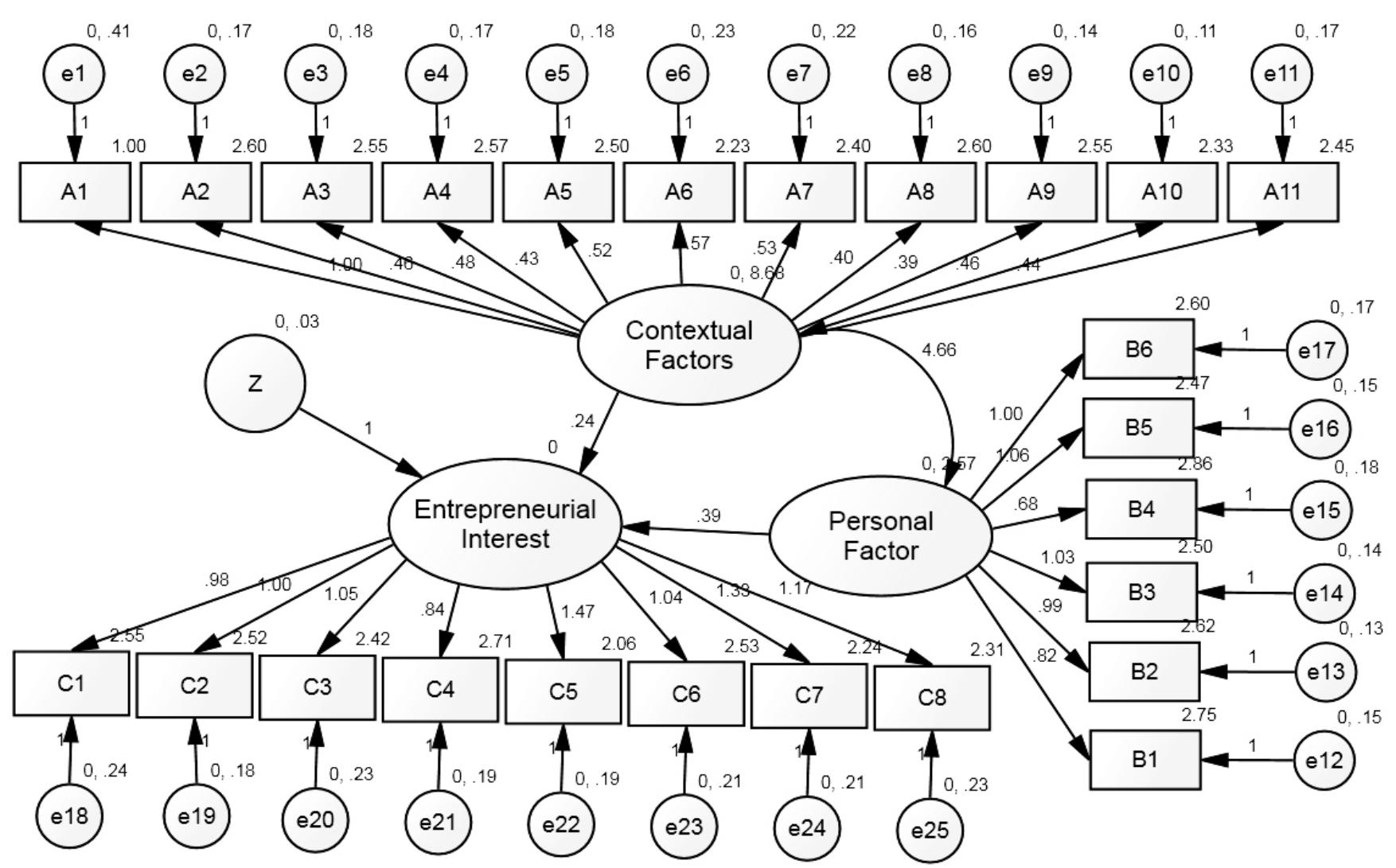

Figure 4. Full structural model

Table 2. Standardized regression weights

\begin{tabular}{llll}
\hline & & & Estimate \\
\hline A1 & $<---$ & F_Contextual & .954 \\
A2 & $<---$ & F_Contextual & .959 \\
A3 & $<---$ & F_Contextual & .960 \\
A4 & $<--$ & F_Contextual & .954 \\
A5 & $<--$ & F_Contextual & .982 \\
A6 & $<--$ & F_Contextual & .963 \\
A7 & $<---$ & F_Contextual & .961 \\
A8 & $<---$ & F_Contextual & .949 \\
A9 & $<---$ & F_Contextual & .954 \\
A10 & $<---$ & F_Contextual & .973 \\
A11 & $<---$ & F_Contextual & .955 \\
B1 & $<---$ & F_Personality & .962 \\
B2 & $<---$ & F_Personality & .977 \\
\hline
\end{tabular}

Reliability Calculation

- Interest in Entrepreneurship $\quad=0,994$

- Personality Factor $\quad=0,988$

- Contextual factors $\quad=0,982$

\begin{tabular}{llll}
\hline & & & Estimate \\
\hline B3 & $<---$ & F_Personality & .977 \\
B4 & $<---$ & F_Personality & .938 \\
B5 & $<---$ & F_Personality & .976 \\
B6 & $<---$ & F_Personality & .970 \\
C1 & $<---$ & i-entrepreneurship & .941 \\
C2 & $<---$ & i-entrepreneurship & .955 \\
C3 & $<---$ & i-entrepreneurship & .949 \\
C4 & $<---$ & i-entrepreneurship & .935 \\
C5 & $<---$ & i-entrepreneurship & .978 \\
C6 & $<---$ & i-entrepreneurship & .953 \\
C7 & $<---$ & i-entrepreneurship & .971 \\
C8 & $<---$ & i-entrepreneurship & .959 \\
\hline
\end{tabular}

Discriminant Validity

The discriminant validity value test is by comparing the square root value of AVE with the correlation value between constructs. AVE square root value ( $\sqrt{ }$ AVE) construct as follows: 
- Interest in Entrepreneurship $=0,954$

- Personality Factor $\quad=0,924$

- Contextual factors $\quad=0,966$

Table 3 shows the value of square root of AVE ( $\sqrt{ }$ AVE). The calculation shows that each latent construct, namely contextual factors, personality factors and interests in entrepreneurship has good discriminant validity. It is said good because the value of each latent constellation value is higher than the correlation value between constructs.

\section{Evaluation of Data Normality}

From the output of normality data, it can be concluded that there is no evidence that the data used has an abnormal distribution, because the value of the critical ratio skewness value is below 2.58. Therefore the assumption of normality has been fulfilled and the data used in this study is feasible to use in subsequent estimates.

\section{Outlier Evaluation}

The criteria used are to pay attention to the Chi-square value of degree of freedom 18, which is the number of indicator variables at the significance level $\mathrm{p}<0.001$. Mahalanobis distance value $\chi^{2}(25 ; 0.001)=52.62$. Thus if the value of the expensive distance in this study is greater than 52.62 is multivariate outliers. But in this study there is no expensive value of the distance that is greater than 52.62 (because the maximum value is 39,731 ), it can be concluded that there are no outliers in the data.

\section{Relationship Between Contextual Factors, Personality Factors and Entrepreneurial Interests}

Testing hypothesis of this study was conducted on two things, namely the influence of contextual factors and personality factors on the interest in entrepreneurship. Testing of the hypothesis in this study is seen from the results of the coefficient standardized regression. The results of the standardized regression coefficient for each hypothesis details are shown in the Table 4.

The standardized regression coefficient in Tables 4 shows that the relationship of constructs of contextual factors to the interests of entrepreneurship is significant at $0.001(\mathrm{p}=* * *)$ with standardized parameter coefficients of 0.524 . This proves that there is an influence between contextual factors on the interest of student entrepreneurship in East Java. Thus it can be said that hypothesis 1 in this study is acceptable. While the standardized regression coefficients in tables 6 also show that the relationship of personality factor constructs to entrepreneurship interests is significant at $0.001(\mathrm{p}=* * *)$ with standardized parameter coefficients of 0.472 . This proves that there is an influence between personality factors on the interest of student entrepreneurship in East Java. Thus it can be said that hypothesis 2 in this study is acceptable. Complete hypothesis conclusions are shown in the Table 5.

Table 3. Output of inter-construct correlation and square root AVE

\begin{tabular}{lccc}
\hline & Contextual factors & Personality factor & Interest in entrepreneurship \\
\hline Contextual factors & 0,966 & & \\
Personality factor & & 0,924 & 0,954 \\
Interest in entrepreneurship & 0,524 & 0,472 & \\
\hline
\end{tabular}

Table 4. Standardized regression weights

\begin{tabular}{llllc}
\hline & & & $\mathrm{P}$ & Estimate \\
\hline I_Entrepreneur & $<---$ & $\mathrm{F}$ _Contextual & $* * *$ & .524 \\
I_Entrepreneur & $<---$ & $\mathrm{F}$ _Personality & $* * *$ & .472 \\
\hline
\end{tabular}

Table 5. Conclusion of the hypothesis

\begin{tabular}{lcccc}
\hline Hypothesis & Standardized coefficient & p-value & Information & Conclusion \\
\hline $\begin{array}{l}\text { There is the influence of contextual factors } \\
\text { on the interest in entrepreneurship }\end{array}$ & 0,524 & $* * *$ & Significant & \\
$\begin{array}{l}\text { There is the influence of personality factors } \\
\text { on the interest in entrepreneurship }\end{array}$ & 0,472 & $* * *$ & Significant & Accept \\
\hline
\end{tabular}




\section{Managerial Implication}

Based on the results of testing on hypothesis 1 that has been proposed, it shows that there is effect of contextual factors on the interest in entrepreneurship. In this case, there is actually an influence $52.4 \%$ and is considered significant at $\mathrm{p}=0.001$. This shows that the existence of academic support in the form of encouragement to issue student ideas and infrastructure support for the practice of establishing a new business in place has an impact on the interest in student entrepreneurship. Then the support of the family, the support of closest friends, the support of people who are considered important, financial support and the increasing amount of information about how to start a business openly influence the interests of entrepreneurs. Wang et al. (2011) stated that children with a family background of entrepreneurs have a higher chance of becoming entrepreneurs.

The test results in hypothesis 2 state that there is an influence between personality factors on the interest in entrepreneurship. This research proves that the personality possessed by students influences the interest in entrepreneurship. Alma (2013) states that the personality possessed by someone can lure others to sympathize with him, people are interested in his conversation, and people are amazed by him. Entrepreneurs who have such personalities often succeed in carrying out their business. A person's personality will determine the type of work or career they choose, including choosing as an entrepreneur. Hypothesis 2 in this study supports the research of Baskara and Has (2018), which states that personality has a positive effect on interest in entrepreneurship.

\section{CONCLUSIONS AND RECOMMENDATIONS}

\section{Conclusions}

Based on the discussion of the hypothesis proposed in this study, the conclusions are as follows: There is an influence of contextual factors on the interest in entrepreneurship. This is based on the output of the parameter coefficients. It is known that the relationship of constructs of contextual factors to the interests of entrepreneurship is significant at $0.001(\mathrm{p}=* * *)$ with standardized parameter coefficients of 0524 . Thus the higher support from external parties (family and friends, education, finance) will further increase students' interest in entrepreneurship. There is the influence of personality factors on the interest in entrepreneurship. This is based on the output of the parameter coefficients on the relationship of personality factor constructs to Significant interest in entrepreneurship at $0.001 \mathrm{c}=$ $* * *)$ with standardized parameter coefficients of 0.472 . Thus the higher his personal will for entrepreneurship and supported by entrepreneurial spirit, the greater the interest in entrepreneurship.

\section{Recommendations}

This study has limitations so that improvements are needed in future studies. Based on the conclusions of this study, the suggestions that can be given by the researcher are: further research should examine further related to other factors that can increase interest in student entrepreneurship. Future research can also try to add moderation variables.

\section{ACKNOWLEDGMENT}

Thank you, the researcher said to the Ministry of Research, Technology and Higher Education who had funded this research in the beginner lecturer research scheme (PDP).

\section{REFERENCES}

Alma B. 2013. Kewirausahaan. Bandung: Alfabeta.

Amir RM, Burhanuddin, Priatna WB. 2018. The Effect Of Individual, Environmental And Entrepreneurial Behavior Factors On Business Performance Of Cassava SMES Agroindustry In Padang City. Indonesian Journal of Business and Entrepreneurship 4(1): 1-10. https://doi. org/10.17358/ijbe.4.1.1.

Aryaningtyas AT. 2018. Dukungan akademik: moderasi hubungan kepribadian proaktif terhadap niat kewirausahaan mahasiswa. Media Ekonomi Dan Manajemen 33(2):175-186. https://doi. org/10.24856/mem.v33i2.699.

Baskara A, Has Z. 2018. Pengaruh Motivasi, Kepribadian dan Lingkungan Terhadap Minat Berwirausaha Mahasiswa Fakultas Keguruan dan Ilmu Pendidikan Universitas Islam Riau (UIR). Peka: Jurnal Pendidikan Ekonomi Akuntansi FKIP UIR 6(1):23-30.

Ciputra. 2009. Quantum Leap Entrepreneurship; Mengubah Masa Depan Bangsa dan Masa 
Depan Anda. Edisi 4, Jakarta: Elex Media Komputindo.

Ferdinand A. 2014. Structural Equation Modeling Dalam Penelitian Manajemen Model-Model Rumit Dalam Penelitian Untuk Skripsi, Tesis dan Disertasi Doktor Edisi 5. Semarang:Badan Penerbit Universitas Diponegoro.

Ghozali I. 2011. Aplikasi Analisis Multivariate Dengan Program SPSS. Semarang: Badan Penerbit Universitas Diponegoro.

Gurbuz G, Aykol S. 2008, Entrepreneurial intentions of young educated public in Turkey. Journal of Global Strategic Management 4(1): 47-56. https://doi.org/10.20460/JGSM.2008218486.

Indarti N, Rostiani R. 2008. Intensi kewirausahaan mahasiswa: studi perbandingan antara Indonesia, Jepang dan Norwegia. Jurnal Ekonomika dan Bisnis Indonesia 23(4).

Inggarwati K, Kaudin A. 2010. Peranan faktor-faktor individual dalam mengembangkan usaha studi kuantitatif pada wirausaha kecil di Salatiga. Integritas - Jurnal Manajemen Bisnis 3(2):185202.

Matiusinaite A, Sekliuckiene J. 2015. Factors determining early internationalization of entrepreneurial SMEs: Theoretical approach. International Journal of Business and Economic Sciences Applied Research 8(3): 21-32.

Mopangga H. 2014. Faktor Determinan minat wirausaha mahasiswa Fakultas Ekonomi Dan Bisnis Universitas Negeri Gorontalo. Jurnal Trikonomika 13(1):78-90.

Kadarsih R, Susilaningsih, Sumaryati S.2013. FaktorFaktor Yang Mempengaruhi Minat Berwirausaha Pada Mahasiswa Program Studi Pendidikan Ekonomi FKIP UNS. Jupe Jurnal Pendidikan Ekonomi UNS 2(1): 95-106.

Nugrahaningsih H, Muslim R. 2016. Pengaruh kepribadian, pengetahuan dan motivasi terhadap minat berwirausaha dengan perencanaan strategis sebagai variabel moderating pada mahasiswa Fakultas Ekonomi di Universitas 17 Agustus 1945 Jakarta. Media Manajemen Jasa Jurnal Online Internasional \& Nasional 3(2):1-20.

Paulus AL. 2018. Entrepreneurship orientation and innovation capability: the role of intellectual resources as mediation (a case study of SMEs furniture in Madiun East Java). Indonesian Journal of Business and Entrepreneurship 4(2):151-160.https://doi.org/10.17358/ ijbe.4.2.151.

Pujiastuti EE. 2013. Pengaruh kepribadian dan lingkungan terhadap intensi berwirausaha pada usia dewasa awal. Buletin Ekonomi 11(1):1-86.

Sholikha N, Harti. 2014. Pengaruh faktor kepribadian terhadap minat berwirausaha pada siswa kelas XI program keahlian pemasaran di SMKN 2 Buduran Sidoarjo. UNESA Journal Of Economic Education 1-14.

SuhartiL,SirineH.2011.Faktor-faktoryangberpengaruh terhadap niat kewirausahaan (entrepreneurial intention) (studi terhadap mahasiswa Universitas Kristen Satya Wacana, Salatiga). Jurnal Manajemen dan Kewirausahaan 13(2): 124 134.https://doi.org/10.9744/jmk.13.2.124-134.

Talas E, Celik AK, Oral IO. 2013. The influence of demographic factors on entrepreneurial intention among undergraduate students as a career choice: the case of a Turkish University. American International Journal of Contemporary Research 3(12): 22-31. https://doi.org/10.2139/ ssrn.2497310.

Tong XF, Tong DYK, Loy LC. 2011. Factors influencing entrepreneurial intention among university students. International Journal of Social Sciences and Humanity Studies 3(1): 487-496.

Uswaturrasul Y, Sisilia K. 2015. Analysis of student's entrepreneurial intention and entrepreneurial motivation (a study on business administration study program, Telkom University, Class of 2011). e-Proceeding of Management 2(3): 35863596.

Wang W, Lu W, Millington JK. 2011. Determinants of entrepreneurial intention among college students in China and USA. Journal of Global Entrepreneurship Research, Winter \& Spring 1(1):35-44.

Walipah, Naim. 2016. Faktor - faktor yang mempengaruhi niat berwirausaha mahasiswa. Jurnal Ekonomi Modernisasi JEKO JEM 12(3):138-144. https://doi.org/10.21067/jem. v12i3.1461.

Yusuf M, Natsir S, Kornelius Y. 2017. Pengaruh kepribadian dan lingkungan keluarga terhadap minat berwirausaha mahasiswa manajemen Fakultas Ekonomi Universitas Tadulako. Jurnal Ilmu Manajemen Universitas Tadulako 3(3): 299-308. 